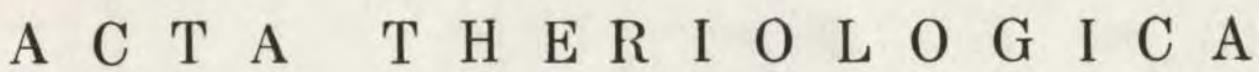 \\ VOL. XIII, 11: 151-176. \\ BIAEOWIEŻA \\ 20.V.1968
}

Barbara CIESIELSKA \& Witold KUPSC

\section{Craniometric Variations in a Population of the Spotted Souslik}

[With 2 Figs. \& 12 Tables]

\begin{abstract}
The aim of these investigations was to analyse sex dimorphism and variations in the development of the skull of Citellus suslicus (G ü 1denstaedt, 1770) on the basis of a sample consisting of 194 individuals. Fisher's discriminant analysis was the method used, and the significance of the results obtained was checked by the Mahalanobis $D^{2}$ test. Sex dimorphism was found in the skull of the souslik, it being particularly marked even in young animals. With the exception of postorbital breadth the mean measurements are greater in males. In young sousliks all the characters are non-discriminant. In adult sousliks the following characters were found to be discriminant in definition of sex dimorphism: maximum length of the skull, maximum nasal breadth, postorbital breadth, maximum height of brain case, mandible length. Changes with development were found in the craniometric characters, the majority of them exhibiting growth with age. Nasal length, frontal length and inter-orbital constriction are most probably stable, altering very little with age, while postorbital breadth even decreases. The most distinctive characters from the aspect of changes with age are: maximum length of the skull, postorbital breadth (in males), and nasal breadth in females. The following regularities in development of the souslik's skull can be distinguished: a) rate of development of different parts of the skull is uneven, and in consequence different discriminant characters dominate in different periods of the animal's life, and different correlations occur; b) proportion between height and length of the skull is maintained in both age groups; c) development of the mandible takes place evenly in all planes; d) the muscles of the mandible exert a considerable effect on the development of the parts of the skull connected with them; e) the frontal region exhibits considerable developmental stability.
\end{abstract}

\section{PROBLEMS DISCUSSED IN THE STUDY}

The aim of this study is to investigate the sex dimorphism and variations in development of the skull of the Spotted souslik, Citellus suslicus (G üldens ta edt, 1770) in one population at Slawęcin near Hrubieszów in the Lublin province. The area inhabited by this population is uniform from the ecological aspect. The skulls were collected over a period of one month. The material is therefore of the required uniformity from the geographical, ecological and seasonal aspects, which permits of assuming that the basic factors forming the variations observed are the sex and age of the animals.

Present address: B. Ciesielska, Warsaw, Komarowa $88 \mathrm{~m} \mathrm{37}$, W. Kupść, Warsaw, J. Bruna $6 \mathrm{~m} 32$. 
The craniometry of the souslik has not as yet been fully elaborated. Some authors only give craniometric measurements, most often within limits wfromto , without unfortunately indicating the number of specimens from which the data are taken (Migulin, 1938; Rešetnik, 1946; Vinogradov \& Gro$\mathrm{mov}, 1952$ ). The number of measurements is most often small (M i g ul in gives 7, Rešetnik 9, Vinogradov \& Gromov-2). The most comprehensive data are those in the study by Ognev (1947), who gives measurements made by $\mathrm{Obolenski}$ in 1927 for 58 individuals of this species. The following are given in respect of 10 measurements: minimum and maximum value, arithmetical mean and index in relation to condylobasal length.

Surdacki (1958) including our material as well, analysed some craniometric problems. His material consisted of 546 individuals from two large colonies in the Lublin region (Slawęcin and Chomęciska), caught in different years and months, and he showed, inter alia, the significance of differences between the two populations in relation to condylobasal length and the significance of sex dimorphism to the same character.

The authors found that in the methods known to them, which have been used up to the present for elaborating the craniometry of small mammals, there was until recently marked predominance of descriptive statistical methods without applying tests giving the reliability of the conclusions reached. For example a frequently encountered basis for drawing conclusions is comparison of the material examined, such as table of frequency distribution, correlation table, multipartite table or graphic interpretation of such a comparison: diagram, histogram, combined with indication of the simplest parameters: range of occurrence of the characters examined and their arithmetical means: e. g. Serebrennikov (1930), Reichstein (1957), Grulich (1960), Sidorowicz (1961), Caboń-Raczyńska (1964a). The interdependence between the characters is usually measured by the coefficient of linear correlation, calculated without taking the effect of classification of material into consideration e. g. Wasilews ki (1952), B on d (1956).

Among studies applying the method of mathematical statistics that by $\mathrm{D}$ e hnel (1949) must first be mentioned. It contains an analysis of variance of the material examined, giving an estimate of arithmetical means (confidence intervals) and value of correlation ratios $\eta^{2}$.

Freedman (1963) analyses 18 craniometric characters of a population of $\mathrm{Pa}$ pio cynocephalus within three geographical groups, giving a list of mean values, standard deviations and mean errors of the arithmetical mean. He draws detailed conclusions as to the differences in some of the characters, making use of the $t$-Student test.

Surdacki (1965) analysed sex dimorphism in Citellus citellus (Linnaeus, 1766) on the basis of 15 craniometric characters of 60 specimens from Nakio. He also compares his material (in respect of condylobasal length) with a souslik population from the Sofia district, using the $\chi^{2}$ criterion.

All the above statistical methods consider populations as one-character communities, and therefore when it is desired to draw conclusions as to several characters it is essential to consider each of them separately. Investigation of a large number of characters and of a community from the angle of a group of characters simultaneously was carried out by Wasilewski (1952), using the Henzel taxonomic method of mean squares of differences, and by $\mathrm{Cabon}-\mathrm{R} a-$ c zyńska (1964b) when examining the relation between 12 craniometric charact- 
ers of Lepus europaeus (Pa1la s, 1778) using the method of Czekanowski's tables and Terentev' correlation pleiads.

The present study forms an attempt at making a multi-character analysis by means of mathematical statistical methods. The method used is a discriminant analysis, comparing communities on the basis of a group of characters and taking the connections between them into consideration. The method of discriminant function introduced by $\mathrm{F}$ isher (1936) is one of the basic methods of multi-character statistical analysis.

\section{MATERIAL AND METHODS}

The skull material used for this study was collected by the first of the authors during the period from July 6 th to 25 th 1955 in the area of one of the largest souslik

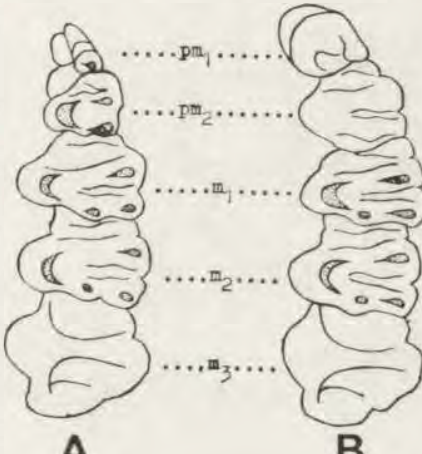

A
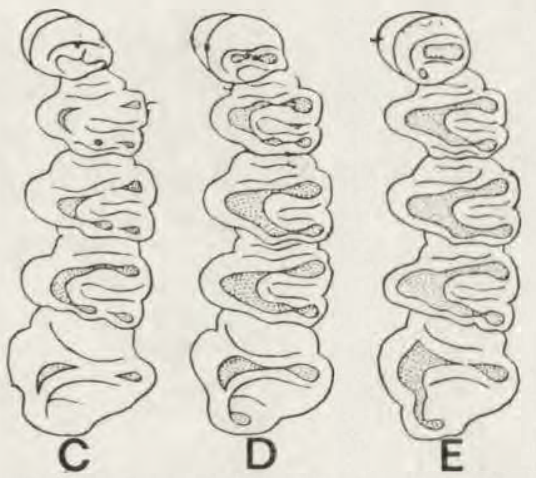

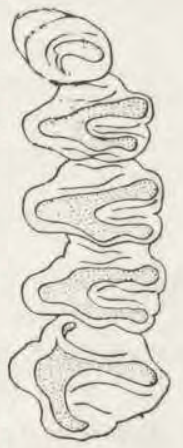

$\mathrm{F}$
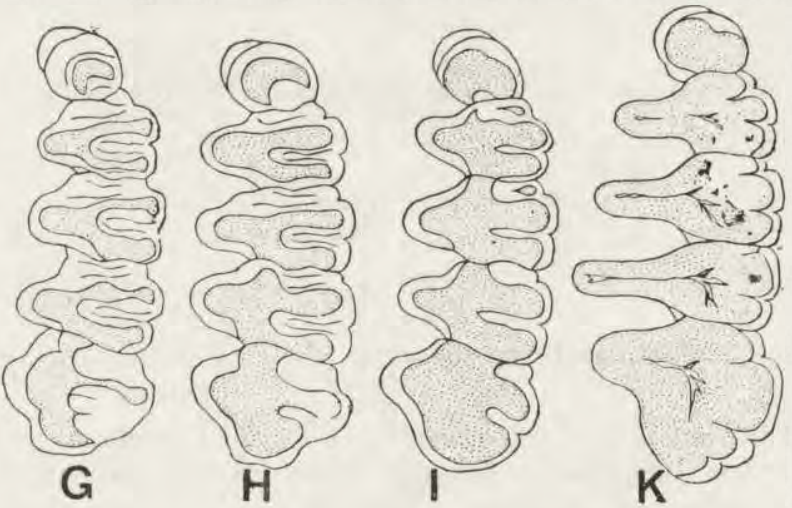

Fig. 1. Developmental changes in the teeth of C. suslicus.

colonies in the Lublin region. Surdacki (1956) gives a detailed description of this colony in his study. The material was classified according to age on the basis of degree of wear of the teeth, the most important for classification purposes being the teeth of the upper jaw (Fig. 1). A key was elaborated for C. suslica based on 
the tooth key given by Ognev (1947) for Citellus pygmaeus (Pallas, 1778). The material was at first divided into 10 age groups of a conventional character, $i$. $e$. not always indicative of the absolute age of the animal. Differences could be seen in the state of the teeth in different groups, but very small numbers of individuals were obtained (particularly older individuals). The whole material was on this account finally divided into two age groups only:

a) young sousliks - born that year, sexually immature. The wear of the enamel on the biting surface of the teeth formed small islets unconnected with each other. These islets do not occur on all of the teeth: there is no wear on $\mathrm{pm}^{1}$ (Fig. $1-\mathrm{A}$, B, C).

b) adult sousliks - sexually mature: adults born before the previous winter and individuals several years old. The enamel is worn on all the teeth, the islets formed are connected in a uniform field (Fig. $1-D, E, F, G, H, I, K$ ).

The guiding principle in choice of measurements was the need to elaborate all the regions of the skull as fully as possible (Fig. 2). Use was made of the treatments
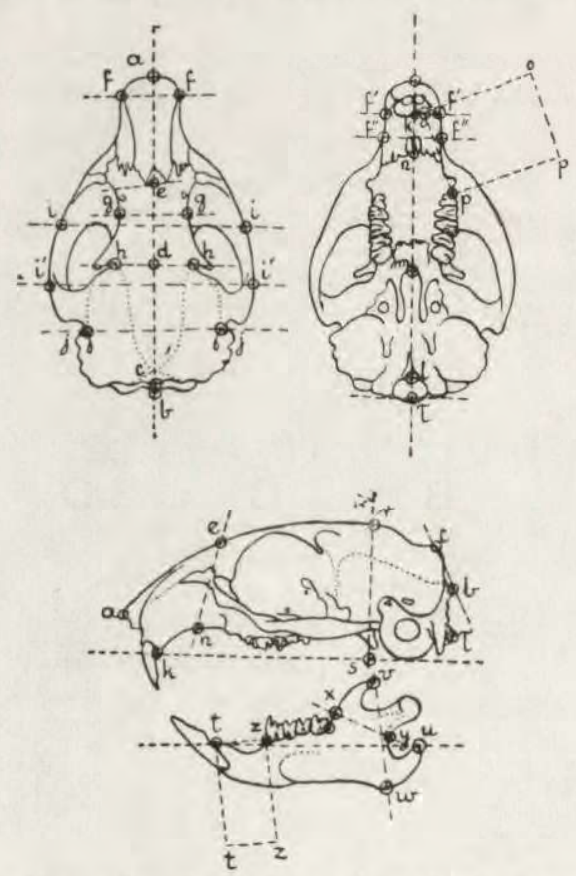

Fig. 2. Skull of C. suslicus showing places in which measurements were made.

described by the following authors in relevant literature, as follows: S e r e brennikov (1930), O gnev (1937 and 1947), Migulin (1938), Rešetnik (1946), Gentile (1952), Cockrum (1954). 25 measurements were established, the definitions of which are given in table 1. The measurements were made by means of a nonius with scale up to $0.1 \mathrm{~mm}$. Measurements of length were made in the medio-sagittal plane, measurements of breadth in the frontal plane. On account of the frequent cases in which the two halves of the mandible were separated along the mental suture during preparation, measurements of this bone such as breadth and length of lower diasteme could not be made in the medio-sagittal plane, but 
Table 1.

Definition of measurements.

\begin{tabular}{|c|c|c|c|}
\hline Symbol & Name & $\begin{array}{l}\text { Measuring } \\
\text { points }\end{array}$ & Definition \\
\hline$x_{1}$ & $\begin{array}{l}\text { Longitudo con- } \\
\text { dylobasalis }\end{array}$ & $k-1$ & $\begin{array}{l}\text { Distance measured along medio-sagittal } \\
\text { line from the line connecting rear } \\
\text { margins of sockets of upper incisors to } \\
\text { a line connecting points reaching furth- } \\
\text { est back on basal condyles. }\end{array}$ \\
\hline$x_{2}$ & $\begin{array}{l}\text { Longitudo } \\
\text { cranii max. }\end{array}$ & $a-b$ & $\begin{array}{l}\text { Distance measured along medio-sagittal } \\
\text { line from the anterior margin of the } \\
\text { nasal bones to the point furthest back } \\
\text { on the occipit. }\end{array}$ \\
\hline$x_{3}$ & $\begin{array}{l}\text { Longitudo } \\
\text { ossis nasalis }\end{array}$ & $a-e$ & $\begin{array}{l}\text { Distance measured along medio-sagittal } \\
\text { line from the anterior margin of the } \\
\text { nasal bones to the line connecting their } \\
\text { margins furthest back. }\end{array}$ \\
\hline$x_{4}$ & $\begin{array}{l}\text { Latitudo } \\
\text { ossis nasalis } \\
\text { max. }\end{array}$ & $f-f$ & $\begin{array}{l}\text { Distance measured vertically to medio- } \\
\text {-sagittal line between points on the } \\
\text { nasal bones situated furthest outside. }\end{array}$ \\
\hline$x_{5}$ & $\begin{array}{l}\text { Latitudo } \\
\text { rostri ant. }\end{array}$ & $f^{\prime}-f^{\prime}$ & $\begin{array}{l}\text { Distance measured vertically to medio- } \\
\text {-sagittal line between points on inter- } \\
\text { maxillary bones situated furthest out- } \\
\text { side, at the height of the posterior } \\
\text { margins of sockets of upper incisors. }\end{array}$ \\
\hline$x_{6}$ & $\begin{array}{l}\text { Latitudo } \\
\text { rostri post. }\end{array}$ & $f^{\prime \prime}-f^{\prime \prime}$ & $\begin{array}{l}\text { As preceding, at the height of posterior } \\
\text { margins of anterior palatal foramina. }\end{array}$ \\
\hline$x_{7}$ & Altitudo rostri & $\mathrm{n}-\mathrm{e}$ & $\begin{array}{l}\text { Distance from point of intersection of } \\
\text { a line connecting the posterior margins } \\
\text { of anterior palatal foramina in medio- } \\
\text {-sagittal plane to a point located in } \\
\text { medio-sagittal plane on line connect- } \\
\text { ing points situated furthest back on } \\
\text { nasal bones. }\end{array}$ \\
\hline$x_{8}$ & $\begin{array}{l}\text { Longitudo } \\
\text { frontalis }\end{array}$ & $e-d$ & $\begin{array}{l}\text { Distance measured along medio-sagittal } \\
\text { line from a line connecting points furth- } \\
\text { est back on nasal bones to a line con- } \\
\text { necting postorbital incisurae. }\end{array}$ \\
\hline$x_{9}$ & $\begin{array}{l}\text { Latitudo } \\
\text { interorbitalis }\end{array}$ & $g-g$ & $\begin{array}{l}\text { Distance measured vertically to medio- } \\
\text {-sagittal line between orbital incisurae. }\end{array}$ \\
\hline$x_{10}$ & $\begin{array}{l}\text { Latitudo post- } \\
\text { orbitalis }\end{array}$ & $h-h$ & $\begin{array}{l}\text { Distance measured vertically to medio- } \\
\text {-sagittal line between postorbital inci- } \\
\text { surae. }\end{array}$ \\
\hline$x_{11}$ & $\begin{array}{l}\text { Latitudo } \\
\text { zygomatic. ant. }\end{array}$ & $i-i$ & $\begin{array}{l}\text { Distance measured vertically to medio- } \\
\text {-sagittal line between points furthest } \\
\text { outside on zygomatic arches, at height } \\
\text { of anterior margin of orbit, seen in } \\
\text { frontal plane. }\end{array}$ \\
\hline$x_{12}$ & $\begin{array}{l}\text { Latitudo } \\
\text { zygomatic. post. }\end{array}$ & $i^{\prime}-i^{\prime}$ & $\begin{array}{l}\text { Distance measured vertically to medio- } \\
\text {-sagittal line between points on zygo- } \\
\text { matic arches situated furthest outside. }\end{array}$ \\
\hline
\end{tabular}




\begin{tabular}{|c|c|c|c|}
\hline Symbol & Name & $\begin{array}{l}\text { Measuring } \\
\text { points }\end{array}$ & Definition \\
\hline$x_{13}$ & $\begin{array}{l}\text { Longitudo } \\
\text { basiliaris }\end{array}$ & $k-1$ & $\begin{array}{l}\text { Distance measured along medio-sagittal } \\
\text { line from line connecting the posterior } \\
\text { margins of sockets of upper incisors to } \\
\text { lower margin of foramen occip. }\end{array}$ \\
\hline$x_{14}$ & Longitudo palat. & $\mathrm{k}-\mathrm{m}$ & $\begin{array}{l}\text { Distance measured along medio-sagittal } \\
\text { line from line connecting posterior } \\
\text { margins of sockets of upper incisors to } \\
\text { line connecting anterior margins of in- } \\
\text { ternal foramina nasales. }\end{array}$ \\
\hline$x_{15}$ & $\begin{array}{l}\text { Longitudo diast. } \\
\text { superior }\end{array}$ & $o-p$ & $\begin{array}{l}\text { Distance measured on left side of skull } \\
\text { from posterior margin of socket of up- } \\
\text { per incisor to anterior margin of socket } \\
\text { of } \text { pm }_{1} \text {. }\end{array}$ \\
\hline$x_{16}$ & $\begin{array}{l}\text { Longitudo neuro- } \\
\text { cranii ant. }\end{array}$ & $e-c$ & $\begin{array}{l}\text { Distance measured along medio-sagittal } \\
\text { line from line connecting points most to } \\
\text { the rear on nasal bones - to crista oc- } \\
\text { cipitalis. }\end{array}$ \\
\hline$x_{17}$ & $\begin{array}{l}\text { Longitudo neuro- } \\
\text { cranii post. }\end{array}$ & $d-b$ & $\begin{array}{l}\text { Distance measured along medio-sagittal } \\
\text { line from line connecting postorbital in- } \\
\text { cisura to upper margin of foramen oc- } \\
\text { cipitale. }\end{array}$ \\
\hline$x_{18}$ & $\begin{array}{l}\text { Latitudo } \\
\text { neurocranii }\end{array}$ & $j-j$ & $\begin{array}{l}\text { Minimum distance measured vertically } \\
\text { to medio-sagittal line between incisurae } \\
\text { behind base of zygomatic processes of } \\
\text { temporal bones. }\end{array}$ \\
\hline$x_{19}$ & $\begin{array}{l}\text { Altitudo } \\
\text { occipitalis }\end{array}$ & $c-b$ & $\begin{array}{l}\text { Distance measured along medio-sagittal } \\
\text { line from crista occip. to upper margin } \\
\text { of for. occip. }\end{array}$ \\
\hline$x_{20}$ & $\begin{array}{l}\text { Altitudo neuro- } \\
\text { cranii max. }\end{array}$ & $\mathrm{r}-\mathrm{s}$ & $\begin{array}{l}\text { Distance from point of intersection of } \\
\text { a line connecting points furthest back } \\
\text { on bullae tympanici in medio-sagittal } \\
\text { plane at place of maximum prominence } \\
\text { upwards of os parietalis. }\end{array}$ \\
\hline$x_{21}$ & $\begin{array}{l}\text { Longitudo } \\
\text { mandibulae }\end{array}$ & $t-u$ & $\begin{array}{l}\text { Distance measured on left half of man- } \\
\text { dible from posterior margin of socket of } \\
\text { lower incisor to point furthest back on } \\
\text { proc. ang. mandibulae. }\end{array}$ \\
\hline$x_{22}$ & $\begin{array}{l}\text { Latitudo man- } \\
\text { dibulae max. }\end{array}$ & $\mathrm{u}-\mathrm{u}$ & $\begin{array}{l}\text { Distance measured vertically to medio- } \\
\text {-sagittal line between points situated } \\
\text { furthest outwards on proc. ang. mandi- } \\
\text { bulae. }\end{array}$ \\
\hline$x_{23}$ & $\begin{array}{l}\text { Altitudo } \\
\text { mandibulae }\end{array}$ & $v-w$ & $\begin{array}{l}\text { Distance measured on left half of man- } \\
\text { dible between points located on ends of } \\
\text { proc. ang. and coronoideus. }\end{array}$ \\
\hline$x_{24}$ & $\begin{array}{l}\text { Latitudo ramus } \\
\text { mandibulae }\end{array}$ & $x-y$ & $\begin{array}{l}\text { Minimum breadth of its ramus measur- } \\
\text { ed on left half of mandible. }\end{array}$ \\
\hline$x_{25}$ & $\begin{array}{l}\text { Longitudo dias- } \\
\text { temae infer. }\end{array}$ & $t-z$ & $\begin{array}{l}\text { Distance measured on left half of man- } \\
\text { dible from posterior margin of socket } \\
\text { of lower incisor to posterior margin of } \\
\text { socket of pm. }\end{array}$ \\
\hline
\end{tabular}


only on one half of the mandible (conventionally - on the left). For the sake of uniformity measurement of the upper diasteme was made only on one (left) half of the skull.

Measurement of height of brain case made it necessary to elaborate a special method on account of the necessity for placing the skull horizontally. The plane connecting the lower margins of the upper incisors with the places reaching furthest downward on bullae tympanici was taken as horizontal. Practically speaking the measurement was made in the following way: a thin straight metal blade was laid along the bottom of the skull so that its front end was supported on the rear margins of the sockets of the upper incisors, while the back end rested on bullae

Table 2.

Mean of measuremens (in $\mathrm{mm}$ ).

\begin{tabular}{|c|c|c|c|c|c|}
\hline \multirow{2}{*}{ Measurements } & & \multicolumn{2}{|c|}{ Juveniles } & \multicolumn{2}{|c|}{ Adultes } \\
\hline & & $\overline{\sigma^{\prime} \sigma^{*}}(\mathrm{~N}=77)$ & ○ी $(\mathrm{N}=63)$ & $\vec{C}^{*} \sigma^{*}(\mathrm{~N}=20)$ & $q \bigcirc(\mathrm{N}=43)$ \\
\hline Long. corp. & & 175.93 & 169.98 & 190.31 & 202.11 \\
\hline Long. caud. & & 44.33 & 43.29 & 43.83 & 44.52 \\
\hline Long. pedis post. & & 33.24 & 31.44 & 32.73 & 31.22 \\
\hline Gravitas corporis (g) & & 131.37 & 120.09 & 266.69 & 198.92 \\
\hline Long. $\mathrm{cb}$. & $x_{1}$ & 36.00 & 34.90 & 39.49 & 37.87 \\
\hline Long. cranii $\max$. & $x_{2}$ & 41.80 & 40.81 & 44.74 & 43.28 \\
\hline Long. oss. nas. & $x_{3}$ & 14.31 & 14.00 & 15.64 & 14.92 \\
\hline Lat. oss. nas. $\max$. & $x_{4}$ & 6.15 & 593 & 6.81 & 6.68 \\
\hline Lat. rostri ant. & $x_{5}$ & 6.43 & 6.28 & 7.21 & 7.00 \\
\hline Lat. rostri post. & $x_{6}$ & 6.21 & 6.05 & 6.76 & 6.59 \\
\hline Alt. rostri & $x_{7}$ & 10.28 & 10.50 & 11.11 & 10.46 \\
\hline Long. front. & $x_{8}$ & 12.97 & 12.40 & 13.24 & 12.79 \\
\hline Lat. interorbit. & $x_{9}$ & 7.77 & 7.60 & 8.43 & 8.08 \\
\hline Lat. postorbit. & $x_{10}$ & 10.66 & 10.60 & 10.18 & 10.35 \\
\hline Lat. zyg. ant. & $x_{11}$ & 21.89 & 21.30 & 24.58 & 23.75 \\
\hline Lat. zyg. post. & $x_{12}$ & 26.19 & 25.54 & 2836 & 27.81 \\
\hline Long. basil. & $x_{13}$ & 33.17 & 32.23 & 36.25 & 35.16 \\
\hline Long. palat. & $x_{14}$ & 20.62 & 19.78 & 22.65 & 21.49 \\
\hline Long. diast. super. & $x_{15}$ & 9.70 & 9.17 & 11.23 & 10.67 \\
\hline Long. neurocr. ant. & $x_{16}$ & 28.75 & 2833 & 30.14 & 29.39 \\
\hline Long. neurocr. post. & $x_{17}$ & 20.11 & 19.93 & 21.22 & 20.68 \\
\hline Lat. neurocr. & $x_{18}$ & 18.03 & 17.86 & 18.36 & 18.10 \\
\hline Alt. occipit. & $x_{19}$ & 5.54 & 5.43 & 6.09 & 5.69 \\
\hline Alt, neurocr, $\max$. & $x_{20}$ & 17.50 & 17.21 & 18.20 & 17.60 \\
\hline Long. mandib. & $x_{21}$ & 25.06 & 24.40 & 27.25 & 26.17 \\
\hline Lat. mandib. $\max$. & $x_{22}$ & 24.97 & 24.20 & 27.59 & 26.61 \\
\hline Alt. mandib. & $x_{23}$ & 14.89 & 1437 & 16.45 & 15.47 \\
\hline Lat. ram. mandib. & $x_{24}$ & 6.54 & 6.25 & 7.16 & 6.77 \\
\hline Long. diast. infer. & $x_{25}$ & 5.76 & 5.28 & 6.38 & 6.12 \\
\hline
\end{tabular}

tympanici. Measurement of height was next made placing one arm of the nonius on the bottom of the metal and the other on the highest place on the skull. The value of thickness of the metal sheet was subtracted from the measurement obtained.

Measurement of rostral height was made in the diagonal plane. The measuring places chosen are clearly defined and the result is fully comparable.

The fact that anly one measurement was made on each skull, which prevented estimation of measuring error, constituted somewhat of a methodological shortcoming. As however the majority of the values measured were clearly defined and the measurements fairly easy to make, estimation of error was made later on 
Table 3.

Definitions of indices.

\begin{tabular}{|c|c|c|}
\hline Indices & Definition & \\
\hline \multirow{2}{*}{ Index lat.-long. cranii } & Lat. zygomatic post. $\left(x_{12}\right)$ & \multirow{2}{*}{ - 100} \\
\hline & Long. cranii $\max .\left(x_{2}\right)$ & \\
\hline \multirow{2}{*}{ Index nasalis } & Lat. ossis nas. $\max .\left(x_{4}\right)$ & \multirow{2}{*}{$\cdot 100$} \\
\hline & Long. ossis nas. $\left(x_{3}\right)$ & \\
\hline \multirow{2}{*}{ Index rostri } & Lat. rostri post. $\left(x_{8}\right)$ & \multirow{2}{*}{$\cdot 100$} \\
\hline & Lat. rostri ant. $\left(x_{5}\right)$ & \\
\hline \multirow{2}{*}{ Index frontalis } & Lat. interorbit. $\left(x_{9}\right)$ & \multirow{2}{*}{$\cdot 100$} \\
\hline & Lat. postorbit. $\left(x_{10}\right)$ & \\
\hline \multirow{2}{*}{ Index zygomat. } & Lat. zyg. ant. $\left(x_{11}\right)$ & \multirow{2}{*}{$\cdot 100$} \\
\hline & Lat. zyg. post. $\left(x_{12}\right)$ & \\
\hline \multirow{2}{*}{ Index diastemae } & Long. diast. sup. $\left(x_{15}\right)$ & \multirow{2}{*}{100} \\
\hline & Long. palat. $\left(x_{14}\right)$ & \\
\hline \multirow{2}{*}{ Index lat.-long. neurocranii } & Lat. neurocr. $\left(x_{13}\right)$ & \multirow{2}{*}{$\cdot 100$} \\
\hline & Long. neur. post. $\left(x_{17}\right)$ & \\
\hline \multirow{2}{*}{ Index alt.-long. neurocranii } & Alt. neur. $\max .\left(x_{20}\right)$ & \multirow{2}{*}{$\cdot 100$} \\
\hline & Long. neur. post. $\left(x_{17}\right)$ & \\
\hline \multirow{2}{*}{ Index alt.-long. mandib. } & Alt. mandib. $\left(x_{2 s}\right)$ & \multirow{2}{*}{$\cdot 100$} \\
\hline & Long. mandib. $\left(x_{21}\right)$ & \\
\hline \multirow{2}{*}{ Index lat.-alt. mandib. } & Lat. ram. mandib. $\left(x_{24}\right)$ & \multirow{2}{*}{100} \\
\hline & Alt. mandib. $\left(x_{23}\right)$ & \\
\hline
\end{tabular}

Table 4.

Mean of indices (in $\%$ ).

\begin{tabular}{|c|c|c|c|c|}
\hline \multirow[b]{2}{*}{ Index: } & \multicolumn{2}{|c|}{ Juveniles } & \multicolumn{2}{|c|}{ Adultes } \\
\hline & $\sigma^{\prime \prime} \sigma^{*}$ & 우 우 & $\sigma^{*} \sigma^{*}$ & 우 \\
\hline Lat.-long. cranii & 62.7 & 62.5 & 63.3 & 64.2 \\
\hline Nasalis & 42.9 & 42.5 & 44.1 & 44.8 \\
\hline Rostri & 85.0 & 83.5 & 86.6 & 85.4 \\
\hline Frontalis & 72.8 & 72,0 & 83.1 & 78.0 \\
\hline Zygomat. & 96.1 & 96.1 & 93.7 & 93.7 \\
\hline Diastemae & 46.3 & 45.1 & 49.4 & 49.6 \\
\hline Lat.-long. neurocr. & 89.7 & 90.0 & 86.7 & 87.6 \\
\hline Alt.-long. neurocr. & 87.2 & 86.7 & 85.9 & 85.1 \\
\hline Lat.-alt. mandib. & 44.3 & 43.6 & 43.7 & 43.5 \\
\hline Alt.-long. mandib. & 59.5 & 59.1 & 60.4 & 59.2 \\
\hline
\end{tabular}


similar material (skulls of a squirrel and hare) which justifies the assumption that the absolute error in measurement is close to the accuracy of the nonius reading, i.e. $0.1 \mathrm{~mm}$ (Standard deviation determined for measurements, repeated 15 times, of maximum length of the squirrel's skull gave a value of $0.115 \mathrm{~mm}$, and $0.17 \mathrm{~mm}$ for the hare).

Table 2 gives the mean value of craniometric measurements in different age and sex groups. Mean values of the basic body measurements are also given in this table.

Calculation was also made of the values of 10 craniometric indices (Table 4). These are mean values of individual indices calculated for each individual. The characters for measurement were chosen so that the indices fully covered the shape of all the regions of the skull (Table 3).

\section{STATISTICAL ELABORATION OF RESULTS}

Elaboration of the results of craniometric measurements made in this study are aimed at: (1) investigating sex dimorphism in the population examined, (2) comparison of craniometric measurements in age groups, (3) examining interdependences between measurements and (4) determining which of the characters examined have the strongest discriminant properties, i.e. which of them make it easiest to distinguish between the populations examined.

The method of discriminant function was used to elaborate the above problems. One of the aims of this method is to compare parameters of multi-character populations, i.e. communities in which each individual is characterized by a group of character values. The collective characteristics of such communities - counterparts of the mean value $m$ and variance $\sigma^{2}$ in a one-character population are formed by the vector

$$
m=\left[\begin{array}{c}
m_{1} \\
m_{2} \\
\vdots \\
\vdots \\
m_{k}
\end{array}\right]
$$

and dispersion matrix

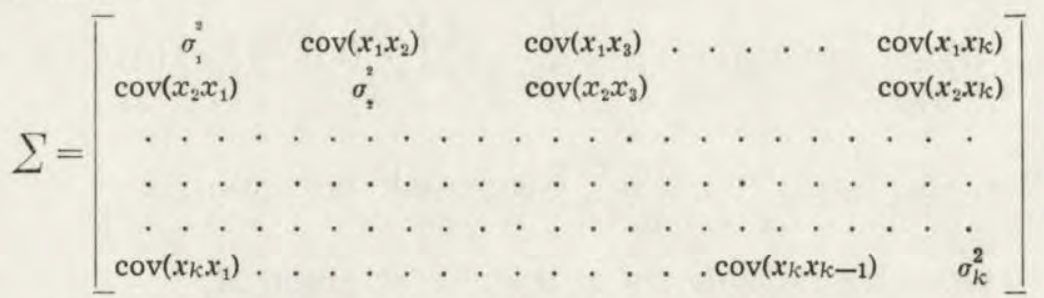

where $m_{i}-$ mean value $i-$ of this character $(i=1,2, \ldots, k)$ 


$$
\begin{aligned}
& \sigma_{i}{ }^{2}-\text { variance } i \text { - of this character } \\
& \operatorname{cov}\left(x_{i} x_{j}\right)-\text { covariance } i-\text { and } j-\text { character } \\
& k-\text { number of characters considered. }
\end{aligned}
$$

Discriminant analysis made in this study was intended to make it possible to compare vectors of the mean values of craniometric characters of sousliks of both sexes and of both the age groups established. This comparison was made by finding, on the basis of empirical data, the discriminant function, i.e. function of the type:

$$
Y=\lambda_{1} x_{1}+\lambda_{2} x_{2}+\lambda_{3} x_{3}+\ldots+\lambda_{k} x_{k}
$$

expressing comparable value - discriminant $(Y)$ of the population examined in values $x_{i}$ of $k$ characters examined by introducing $\lambda_{i}$ coefficients. The geometrical picture of the right side of equality (3) equated to zero is the $k$-dimension hyperplane (for $k=2$ straight line, for $k=3$ plane). The way in which $\lambda_{i}$ coefficients are found is as follows. The expression of

$$
\text { (4) }\left(\lambda_{1} d_{1}+\lambda_{2} d_{2}+\ldots+\lambda_{k} d_{k}\right)^{2} \text {, }
$$

where: $d_{i}=m_{A i}-m_{B i}$,

$$
\begin{aligned}
& m_{A i}-\text { mean value of } i-\text { character of group } A, \\
& m_{B i}-\text { mean value of } i-\text { character of group } B
\end{aligned}
$$

is the variation between groups $A$ and $B$ (e.g. sexes) while the expression of

$$
\sum_{i=1}^{k} \sum_{j=1}^{k} \lambda_{i} \lambda_{j} \operatorname{cov}\left(x_{i} x_{j}\right)
$$

is the variation within these groups. When it is desired to estimate $\lambda_{i}$ on the basis of data from the sample the following formula is used:

(6) $d_{i}=\bar{x}_{A i}-\bar{x}_{B i} \quad(\bar{x}$ - mean value from sample $)$

and

$$
\begin{aligned}
\operatorname{cov}\left(x_{i} x_{j}\right)= & \frac{1}{N_{A}+N_{B}-2}\left[\sum_{t=1}^{N_{A}}\left(x_{A i t}-\bar{x}_{A i}\right)\left(x_{A j t}-\bar{x}_{A j}\right)+\right. \\
& \left.+\sum_{t=1}^{N_{B}}\left(x_{B i t}-\bar{x}_{B i}\right)\left(x_{B j t}-\bar{x}_{B j}\right)\right]
\end{aligned}
$$

where: $N_{A}$ - numbers of sample for group $A$,

$N_{B}$ - numbers of sample for group $B$. 
The relation of these two variations is next considered in the form of

$$
\frac{N_{A} \cdot N_{B}}{N_{A}+N_{B}} \times \frac{\left(\sum_{i=1}^{k} d_{i} \lambda_{i}\right)^{2}}{\sum_{i=1}^{k} \sum_{j=1}^{k} \lambda_{i} \lambda_{j} \operatorname{cov}\left(x_{i} x_{j}\right)}
$$

demanding that it reaches maximum. This corresponds to the postulate that the variation of value of function $\mathrm{Y}$ should be as small as possible within the groups and as great as possible between groups represented by their arithmetical means. The expression (8) attains maximum value when its denominator is minimal with constant $(C)$ value of numerator. Formulating $\sum_{i=1}^{k} d_{i} \lambda_{i}=C$ and using the method of Lagrangian multipliers the following system of equations is obtained for calculating (with accuracy to proportionality) of $\lambda_{i}$ coefficients

$$
\lambda_{1} \operatorname{cov}\left(x_{i} x_{1}\right)+\lambda_{2} \operatorname{cov}\left(x_{i} x_{2}\right)+\ldots+\lambda_{k} \operatorname{cov}\left(x_{i} x_{k}\right)=C d_{i} .
$$

Assuming $C=1$ and using the formula

$$
r_{i j}=\frac{\operatorname{cov}\left(x_{i} x_{j}\right)}{s_{i} s_{j}},
$$

where: $r_{i j}$ - sample coefficient of linear correlation between characters $i$ and $j$;

$s_{i}, s_{j}$ - standard deviations in the sample, we can obtain after simple conversions a system of equations more convenient in calculations

$$
\lambda_{1}^{\prime} r_{i 1}+\lambda_{2}^{\prime} r_{i 2}+\ldots+\lambda_{k}^{\prime} r_{i k}=d_{i}^{\prime},
$$

where:

$$
\lambda_{j}^{\prime}=\lambda_{j} s_{j}, \quad d_{i}^{\prime}=d_{i} / s_{i} .
$$

Multiplying equations (11), the first by $\lambda_{1}^{\prime}$, the second by $\lambda_{2}^{\prime}, \ldots, k-$ by $\lambda_{k}^{\prime}$ and adding each side we obtain

$$
\sum_{i=1}^{k} \sum_{j=1}^{k} \lambda_{i}^{\prime} \lambda_{j}^{\prime} r_{i j}=\sum_{i=1}^{k} \lambda_{i} d_{i}^{\prime}=\sum_{i=1}^{k} \lambda_{i}^{\prime} s_{i} \frac{d_{i}}{s_{i}}=\sum_{i=1}^{k} \lambda_{i} d_{i}=D^{2},
$$

where $D^{2}$ is the measure of distance (introduced by Mahalanobis) between communities $A$ and $B$. Distance obtained in this way is, as can be seen from (12) invariable in relation to the linear transformations of the $x_{i}$ characters examined.

After finding the discriminant function and defining $D^{2}$, the significance of the value obtained is checked by the test proper to the given 11 - Acta theriol. 
method of finding the function. In the present study we used the expression having the following form (O lekiewicz, 1962):

$$
\frac{N_{A} \cdot N_{B}\left(N_{A}+N_{B}-k-1\right)}{k\left(N_{A}+N_{B}\right) \cdot\left(N_{A}+N_{B}-2\right)} \times D^{2}
$$

This value, when we assume that the communities examined are subject to normal $k$-dimension distribution and that the corresponding variances and covariances equal each other, has the $F$-Fisher-Snedecor distribution with $k$ and $N_{A}+N_{B}-k-1$ degrees of freedom.

When the given function is found to have discriminant capacity [significance of expression (13)], it may be interesting to ascertain which of the characters or groups of characters have the strongest selective properties - which in the given group best distinguish the population examined. The absolute of $\lambda_{i}^{\prime}$ coefficients gives the best approximate information on this, while the following test supplies detailed indices.

Let us assume that we are interested in group $r$ among $k=r+p$. We consider value $D^{2}$ defined for all the characters and $D^{2}$ only for $p$ undistinguished. The value $D^{2}$ fulfils the basic postulates of distance: it cannot diminish with an increase in the number of components of vector $d_{i}$. We make use of this fact in constructing the test. The expression

$$
R=\frac{1+\frac{N_{A} \cdot N_{B}}{\left(N_{A}+N_{B}\right) \times\left(N_{A}+N_{B}-2\right)} \times D_{k}^{2}}{1+\frac{N_{A} \cdot N_{B}}{\left(N_{A}+N_{B}\right) \times\left(N_{A}+N_{B}-2\right)} \times D_{p}^{2}},
$$

where $D_{k}^{2}-$ value $D^{2}$ for all $r+p=k$ characters

$D_{\mathrm{p}}^{2}$ - value $D^{2}$ for $p$ undistinguished characters, should be close to unity when there is no distinctiveness of $r$ additional characters. When this is not so, it forms evidence that $r$ additional characters significantly affect the discriminant capacity of $Y$ function. With assumptions as for formula (13) the expression

$$
\frac{N_{A}+N_{B}-p-r-1}{r} \times(R-1)
$$

also has the $F$-Fisher-Snedecore distribution with $r$ and $N_{A}+N_{B}-$ $-p-r-1$ degrees of freedom and serves to test of the above hypothesis.

The fact that coefficients of correlation $r_{i j}$ were determined by means of one-way analysis of variance and covariance makes it possible to 
draw conclusions as to differences between the groups examined also of course in relation to different characters separately. When verifying hypotheses during elaboration the significance level $\alpha=0.01$ or 0.05 was accepted.

On account of the different number of skulls for the two sexes and the age groups established it was impossible to carry out the discriminant analysis described above within both these classifications simultan€ously. Four comparisons were therefore made independently of each other:

1) comparison of measurements for sex in the "adult " age group,

2) comparison of measurements for sex in the "young " age group,

3) comparison of measurements for age groups among males,

4) comparison of measurements for age groups among females.

When choosing the characters elaborated in the first place we rejected indices which were functions of measures as secondary values. Next for the first analysis - investigations of sex dimorphism in the group of adult sousliks - the number of 25 measurements was reduced to the following 13:

a) those concerned with general dimensions of the skull - $\mathrm{Cb}$. length, maximum length of skull, posterior zygomatic breadth, maximum height of brain-case,

b) those concerned with the rostral part - nasal length, maximum nasal breadth,

c) those concerned with the frontal part - frontal length, interorbital constriction, postorbital breadth,

d) those concerned with the neurocranium - posterior cranial length, breadth of brain case,

e) those concerned with the mandible - length and height of mandible.

The characters chosen in this way describe all the main regions of the skull, and their number permits of practical calculations of discriminant analysis. It must be emphasised that it would be possible to avoid so arbitrary a choice of characters at the expense of certain additional calculations connected with the sequence method of discriminant analysis proposed by Olekiewicz (1962), which consists in consecutive introduction of $2,3,4$ etc. most selective characters.

\section{RESULTS}

In the first elaboration we used the 13 characters given above; in the next we limited ourselves to the following characters: maximum length of skull, maximum nasal breadth, postorbital breadth, maximum height of brain case, length of mandible. 


\section{Investigation of Sex Dimorphism in the Group of Adults}

The material consisted of 60 skulls of adult sousliks, $20 \sigma^{\top} \sigma^{\top}$ and 40 우오. The following pairs of characters exhibited marked rectilinear relation: $\mathrm{Cb}$ length and maximum length of skull, $\mathrm{Cb}$ length and length of mandible, maximum length of skull and length of mandible. The only character exhibiting negative correlations with the remainder is the postorbital breadth. The values of the coefficients of correlation are, however, generally very near zero for it. (Closest connection with height of mandible $r=-0,34$ - Table 5).

When examining variations of different characters analysis of variance revealed the significance of dimorphic differences for the following characters: $\mathrm{Cb}$ length, maximum length of skull, posterior zygomatic breadth, maximum height of brain case, nasal length, frontal length, interorbital constriction, posterior length of brain case, breadth of brain case, length of mandible, height of mandible. The mean values of these characters are greater for males. No significant dimorphic differences were revealed for the following characters: maximum nasal breadth and postorbital breadth, the latter character having a greater mean value in females. The discriminant function found has the following form:

$$
\begin{aligned}
& Y=3.1418 x_{1}+7.7009 x_{2}-1.2293 x_{3}-3.0094 x_{4}-0.9264 x_{8}+ \\
& 0.3850 x_{9}-6.0256 x_{10}+0.7095 x_{12}-1.9522 x_{17}-0.0532 x_{13}+ \\
& 8.4679 x_{20}-10.4083 x_{21}+3.3452 x_{23}
\end{aligned}
$$

Value $D^{2}$ calculated for this function was 12.39 and the values of test $F=10.08$ reveals, in comparison with the table value $F_{0.01}=2.54$ (for the 13 and 46 degrees of freedom) highly significant differences in skull measurements of the souslik in respect of sex.

In order further to reduce the material 7 characters were chosen possessing the maximum absolute values $\lambda_{i}^{\prime}$ : Cb length $\left(x_{1}\right)$, maximum length of skull $\left(x_{2}\right)$, maximum nasal breadth $\left(x_{4}\right)$, postorbital breadth $\left(x_{10}\right)$, maximum height of brain case $\left(x_{20}\right)$, lenght of mandible $\left(x_{21}\right)$, height of mandible $\left(x_{23}\right)$ and the discriminant function calculated for them in the following form:

$$
\begin{aligned}
& Y=2.4974 x_{1}+4.2964 x_{2}-5.3285 x_{4}-5.4114 x_{10}+3.5087 x_{20}- \\
& 6.3386 x_{21}+0.2843 x_{23}
\end{aligned}
$$

The expression $D^{2}$ has a value 9.21 for this function, which in comparison with $D^{2}$ for 13 characters by means of $R$ test (formulae 14 and 15) gives the value $F=1.80$, which with $F_{0.05}$ (6 and 46 degrees of freedom) $=2.32$ does not exhibit significant differences in distance $D^{2}$ for 7 and 13 characters. 


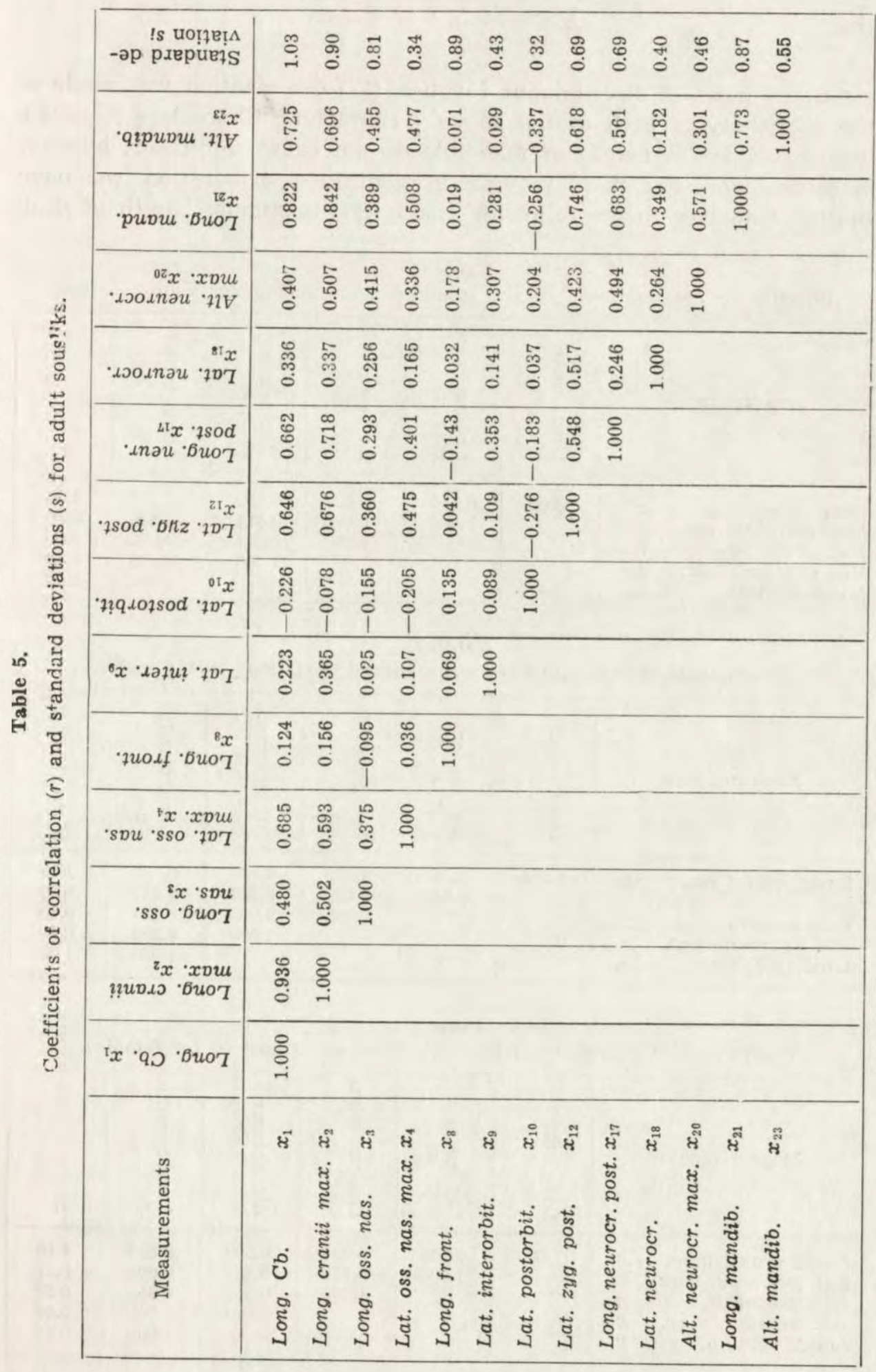


On the basis of discriminant function (17) examination was made of the selectivity of each of the above 7 characters. Characters $x_{1}-\mathrm{Cb}$ length and $x_{23}$ - height of mandible do not cause significant increase in distance $D^{2}$. For these reasons in continued elaboration we have limited ourselves to the following characters: maximum length of skull

Table 6.

Coefficients of correlation $(r)$ and standard deviations $(s)$ for young susliks.

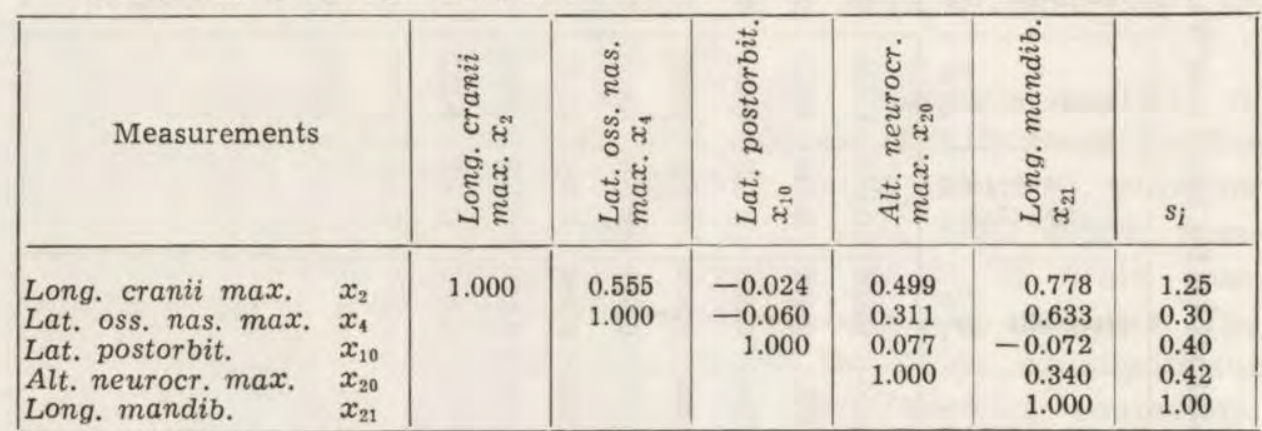

Table 7.

Coefficients of correlation $(r)$ and standard deviations $(s)$ for males.

\begin{tabular}{|c|c|c|c|c|c|c|c|}
\hline Measurements & & 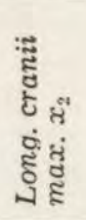 & 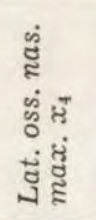 & 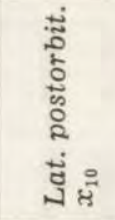 & 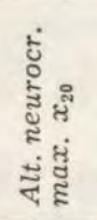 & 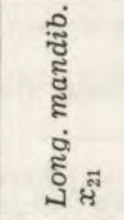 & 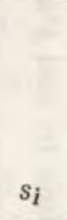 \\
\hline $\begin{array}{l}\text { Long. cranii max. } \\
\text { Lat. oss. nas. max. } \\
\text { Lat. postorbit. } \\
\text { Alt. neurocr. max. } \\
\text { Long. mandib. }\end{array}$ & $\begin{array}{l}x_{2} \\
x_{4} \\
x_{10} \\
x_{20} \\
x_{21}\end{array}$ & 1.000 & $\begin{array}{l}0.546 \\
1.000\end{array}$ & $\begin{array}{r}-0.032 \\
-0.169 \\
1.000\end{array}$ & $\begin{array}{l}0.566 \\
0.117 \\
0.005 \\
1.000\end{array}$ & $\begin{array}{r}0.782 \\
0.517 \\
-0.224 \\
0.266 \\
1.000\end{array}$ & $\begin{array}{l}1.09 \\
0.32 \\
0.40 \\
0.40 \\
1.02\end{array}$ \\
\hline
\end{tabular}

Table 8.

Coefficients of correlation $(r)$ and standard deviations $(s)$ for females.

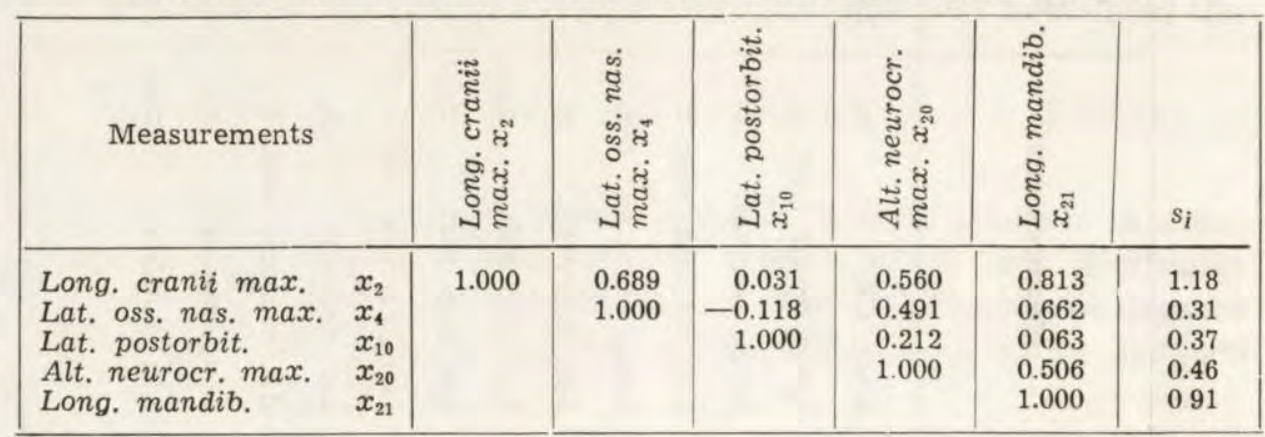


$\left(x_{2}\right)$, maximum nasal breadth $\left(x_{4}\right)$, postorbital breadth $\left(x_{10}\right)$, maximum height of brain case $\left(x_{20}\right)$ and length of mandible $\left(x_{21}\right)$.

\section{Investigation of Sex Dimorphism in the Young Group}

The material consisted of 134 skulls $-710^{x} 0^{x}$ and 63 우. Analysis was made for 5 characters: $x_{2}, x_{4}, x_{10}, x_{20}, x_{21}$. Table 6 gives coefficients of correlation and standard deviations. The following pairs of characters exhibit the strongest rectilinear relation: maximum length

Table 9.

Results of investigation of distinctiveness of characters revealing sex dimorphism in the group of adult sousliks.

\begin{tabular}{|l|c|c|c|c|}
\hline$x_{i}$ & $\begin{array}{r}D^{2} \text { for } 6 \text { characters } \\
\text { without } x_{i}\end{array}$ & $F_{\text {emp }}$ & Significance & $F_{(0.05 ; 1,52)}$ \\
\hline$x_{1}$ & 8.70 & 2.04 & - & \\
$x_{2}$ & 7.98 & 5.18 & + & \\
$x_{4}$ & 7.62 & 5.89 & + & 4.04 \\
$x_{10}$ & 7.41 & 6.00 & + & \\
$x_{20}$ & 7.97 & 5.21 & + & \\
$x_{21}$ & 4.45 & 0.15 & + & \\
$x_{23}$ & 9.20 & 0.03 & - & \\
\hline
\end{tabular}

Table 10.

Results of investigation of distinctiveness of characters revealing sex dimorphism in the group of young sousliks.

\begin{tabular}{|l|c|c|c|c|}
\hline$x_{i}$ & $\begin{array}{r}D^{2} \text { for 4 characters } \\
\text { without } x_{i}\end{array}$ & $F_{\text {emp }}$ & Significance & $F_{(0.05 ; 1,128)}$ \\
\hline$x_{2}$ & 0.821 & 1.43 & - & \\
$x_{4}$ & 0.777 & 2.65 & - & 3.92 \\
$x_{10}$ & 0.849 & 0.69 & - & \\
$x_{20}$ & 0.779 & 2.60 & - & \\
$x_{21}$ & 0.873 & 0.01 & - & \\
\hline
\end{tabular}

of skull and nasal breadth, maximum length of skull and length of mandible, nasal breadth and length of mandible.

When each of the characters were examined all were found to exhibit significant differences in mean values in favour of males.

Discriminant function for the population of young individuals is defined by the formula

(18) $Y=0.3016 x_{2}+1.3179 x_{4}+0.3983 x_{10}+0.8706 x_{20}+0.0187 x_{21}$ Value $D^{2}=0.874$ gives significant value of the test $F=5.66$ with $F_{0.01}$ ( 5 and 128 degrees of freedom) $=3.14$ which indicates differences in craniometric characters of young sousliks depending on sex. 
Examination of distinctiveness of different characters (Table 10) indicates that none of the 5 characters introduces any additional significant value $D^{2}$ in the group, despite the fact that each taken separately and also their group exhibits significant differences between the sexes.

\section{Comparison of Age Groups for Males}

The material consisted of 91 skulls, 20 adult and 71 young. 5 characters, the same as in the foregoing comparison (Table 7), were examined. The strongest rectilinear dependence is exhibited by the

Table 11.

Results of investigation of distinctiveness of characters in age groups for males.

\begin{tabular}{|l|c|c|c|c|}
\hline$x_{i}$ & $\begin{array}{r}D^{2} \text { for } 4 \text { characters } \\
\text { without } x_{i}\end{array}$ & $F_{\text {emp }}$ & Significance & $F_{(0.05 ; 1,85)}$ \\
\hline$x_{2}$ & 8.17 & 6.01 & + & \\
$x_{4}$ & 8.69 & 2.76 & - & 3.96 \\
$x_{10}$ & 8.11 & 6.41 & - & \\
$x_{20}$ & 8.99 & 0.92 & - & \\
$x_{21}$ & 9.10 & 0.30 & & \\
\hline
\end{tabular}

Table 12.

Results of investigation of distinctiveness of characters in age groups for females.

\begin{tabular}{|l|c|r|r|c|}
\hline$x_{i}$ & $\begin{array}{r}D^{2} \text { for } 4 \text { characters } \\
\text { without } x_{i}\end{array}$ & $F_{\text {emp }}$ & Significance & $F_{(0.05 ; 1,97)}$ \\
\hline$x_{2}$ & 6.36 & 2.10 & - & \\
$x_{4}$ & 5.20 & 14.41 & + & \\
$x_{10}$ & 6.46 & 1.16 & - & 3.94 \\
$x_{20}$ & 6.33 & 2.36 & - & \\
$x_{21}$ & 6.55 & 0.31 & - & \\
\hline
\end{tabular}

following characters: maximum length of skull with the characters, nasal breadth, height of brain case, length of mandible; nasal breadth and length of mandible. Examination of each character revealed significant differentiation in all 5 , the mean postorbital breadth being greater for young sousliks, and the means of other characters for adults. The discriminant function takes the following form:

(19) $Y=2.0144 x_{2}+2.7359 x_{4}-2.7775 x_{10}+1.3625 x_{20}-0.4056 x_{21}$ Value $D^{2}=9.15$ calculated on its basis gives the significant value $F=27.28$ with $F_{0.01}=3.27$ (for 5 and 85 degrees of freedom). This points to differences between the age groups in the male population. 
The characters: maximum length of skull $\left(x_{2}\right)$ and postorbital breadth $\left(x_{10}\right)$ exhibit significant increase of distance $D^{2}$, that is, they possess the strongest distinctive properties in this group of characters (Table $11)$.

\section{Comparison of Age Groups for Females}

The material consisted of 103 skulls, 63 young and 40 adult. The following characters exhibit the greatest coefficients of correlation (Table 8) for females: maximum length of skull with nasal breadth, height of brain case and length of mandible; nasal breadth and length of mandible - that is, the same characters as in males.

Analysis of variance of different characters revealed differences in each of the 5 characters considered. Postorbital breadth is greater for the young group, the remaining characters exhibit greater mean values for adults. The discriminant function takes the form:

(20) $Y=0.8350 x_{2}+5.6073 x_{4}-1.0358 x_{10}-1.4041 x_{20}+0.3657 x_{21}$

Value $D^{2}=6.59$ calculated on its basis is significant $(F=30.98$, with $F_{0.01}$ for 5 and 47 degrees of freedom equal to 3.22 ) which points to differences between the age groups among females.

In the group of characters examined the character $x_{4}-$ maximum nasal breadth - exhibited significant distinctiveness (Table 12).

\section{ANALYSIS OF RESULTS}

\section{Sex Dimorphism}

In this study we have shown, by examining a group of characters, that strongly marked sex dimorphism occurs in the skulls of sousliks, the great majority of the characters exhibiting mean values greater in the case of males. This provides complete confirmation of the results obtained by Surdacki $(1958,1965)$ for C. suslicus and C. citellus. It is only the postorbital breadth which is greater in females, significant differences in this character being shown in the group of young sousliks. Thus it is only this character which is an exception to the agreement of skull variations in sousliks with the general rule for mammals, that males attain greater dimensions than females. Postorbital breadth is generally, as we shall see later on, of a somewhat specific character and variations in it differ to a considerable extent from the general trend of variation of other measurements.

Dimorphism is already distinctly marked in young sousliks, as S u rd a cki (1958) also found. All the characters examined exhibited signi- 
ficant differences between the sexes. Among adult sousliks it was only nasal breadth and postorbital breadth which did not exhibit significant sex differences.

The method of discriminant analysis used in this study also made it possible, in addition to investigating the significance of differences between the sexes, to choose characters most distinctive in respect of sex.

In the material examined all characters proved to be equally undiscriminant among the young sousliks, but among adult individuals only the $\mathrm{Cb}$ length and height of mandible proved undiscriminant. There is therefore a marked lack of stabilization of the properties of characters in young sousliks, they are labile, which results in none of the characters being of greater importance than others in revealing differences between the sexes. The non-distinctiveness of $\mathrm{Cb}$ length is remarkable in adult sousliks, and this fact can be explained by the strong correlation of this character with the majority of the other characters.

When young sousliks are compared with adults from the aspect of distinctiveness we may reach the conclusion that the development of different characters is to some extent parallel in young animals (all characters being non-distinctive), but that this alters later on in life, so that some of the characters become outstandingly distinctive.

Among the distinctive characters the nasal breadth, which does not exhibit significant dimorphic differences, is remarkable. It forms an example of the different properties of a character depending on whether it is considered separately, or in a group of other characters.

In young sousliks the strongest correlation is exhibited by maximum length of skull with mandibular length, nasal breadth with mandibular length, maximum length of skull with nasal breadth. The first of these correlations forms evidence of the even development of the skull in the sagittal plane, the mandible growing parallel to the upper parts of the skull. The second correlation is difficult to interpret from the natural science point of view. It cannot be explained by the correlation of the two characters considered with the length of skull, since partial coefficient of correlation of nasal breadth with mandibular length, after elimination of the effect of skull length, still has a fairly high value $(0.443)$. The last correlation points to the fact of parallel development of the whole skull in the sagittal plane and rostrum in the frontal plane.

In the group of adult sousliks three correlations occurring between $\mathrm{Cb}$ length, maximum length of skull and length of mandible are most strongly expressed $(r>0.8)$. The strong correlation connection between 
$\mathrm{Cb}$ length and maximum length of skull results from the fact that these measurements are very similar to each other in adult souliks. Wasilewski (1952) found progressive elongation with age of the base of the skull, and consequent increasingly closeness of measurement of $\mathrm{Cb}$ length to maximum length of skull in Clethrionomys glareolus ( $\mathrm{S} \mathrm{chreber}, 1780)$. This absence of rectilinear relation between the measurements given does not therefore coincide with the results of the present study. Correlation between $\mathrm{Cb}$ length and mandible length is evidence of the even growth of the skull as a whole in the sagittal plane, the mandible "keeping abreast « with the upper parts in its development. The correlation between maximum length of skull and length of mandible can be explained as due to the two foregoing, since corresponding partial coefficients of correlation (defined after eliminating the third of the characters considered above) are: for $\mathrm{Cb}$ length and maximum length of skull 0.57 ; for $\mathrm{Cb}$ length and mandibular length 0.55 , but only 0.22 for maximum length of skull and length of mandible.

The following are correlated to a slightly smaller degree $(r>0.7)$ in adult sousliks: length of mandible and height of mandible, posterior zygomatic breadth and length of mandible, $\mathrm{Cb}$ length and height of mandible and posterior length of brain case and maximum length of skull. The first correlation is evidence of the even development of the mandible in its two main planes. The second correlation would appear to be due to the strong influence of the muscles of the mandible both on itself and on the zygomatic arches. Correlation between $\mathrm{Cb}$ length and height of the mandible is due to the close connection of both these characters with mandibular length. Elimination of the influence of this character results in the partial coefficient of correlation between $\mathrm{Cb}$ length and mandibular height taking the value 0.22 . Correlation of posterior length of brain case with maximum length of skull, with simultaneous occurrence of correlation between $\mathrm{Cb}$ length and maximum length of brain case $(r=0.66)$ is evidence of the even development of different parts of the skull in the sagittal plane. This conclusion does not coincide with the results obtained by Wasilewski (1952) who found in C. glareolus elongation with age of the base of the skull in relation to the occipital part and consequent perpendicularization of the foramen occipitalis.

Among the remaining more marked correlations $(r>0.6)$ that between $\mathrm{Cb}$ length and nasal breadth is remarkable, forming evidence of broadening of the rostrum parallel to the growth of the skull in the sagittal plane,

Great divergences can be observed between young and adult sousliks 
when comparison is made of correlation relationships. This fact should most probably be explained by the uneven rate of development of different areas of the skull and the consequent domination of different regularities at different periods of the animal's life.

Differences in the correlation matrix of craniometric characters between age groups are also confirmed by $\mathrm{Cabon}-\mathrm{R} a \mathrm{czy}$ nk $\mathrm{k}$ 's study (1964b).

When considering correlation coefficients the postorbital breadth, which with the majority of the other characters gave negative coefficients, is remarkable. Numerous authors who elaborated the skulls of small mammals (O g nev, 1947; W a silew ski, 1952; W asilewski, 1952b; Zimmermann, 1955) observed that this character may decrease with age. The present study confirms this assumption, since both for females and males this value differs significantly in favour of the young animals.

Among the characters exhibiting close connections with others the absence of such characters as nasal length, frontal length and interorbital constriction are remarkable. According to $\mathrm{Kubik}$ (1957) in Arvicola nasal length is a character subject to little variation, only to a slight degree correlated with condylobasal length (he does not give the value of the coefficient of correlation). Wasilewski (1952), on the other hand, found in $C$. glareolus a constant increase, although diminishing with age, of this character. There are no data in literature on frontal length. It is possible that the whole frontal region is subject to little variation, is stable, and this would explain the absence of a connection both of frontal length and interorbital constriction with the other characters. The fact established by K u bik $(1952,1953)$ that there is extremely little variation in frontal breadth in Sicista betulina (P a lla s, 1779) and Micromys minutus (P a llas, 1778), which as the author himself states, forms the exception to the general rule for rodents, argues in favour of this interpretation.

Such distinct sex dimorphism found in the skulls of sousliks differs slightly from the results obtained by other authors in studies on small rodents. For instance Wasilewski (1952) found only slight sex dimorphism in C. glareolus, manifested by greater breadth of the brain case and span of the zygomatic arches in relation to the length dimensions of the skull in females that is the case with males. W a sile wski (1956) did not find sex dimorphism to exist at all in Microtus oeconomus ( $\mathrm{P}$ a lla s, 1776).

These differences would seem to be understandable in view of the fact that the souslik is fairly distant systematically from the above genera, and differs from them considerably from the physiological and 
ecological aspects. It might be interesting to compare the results of the present study with analogical ones for the squirrel - Sciurus (L in$\mathrm{n}$ a e us, 1758), a genus systematically closest to the genus Citellus (O ke n, 1816). Unfortunately the only craniometric studies known to the authors on squirrels (Serebrennikov, 1930; Sidorowicz, 1958 ; 1961) do not contain enough statistical material to make such comparison possible.

\section{Age Variations}

In the present study the whole material was divided into two age groups only, young and adult sousliks. It is obvious that such division of a population makes detailed investigation of variations in development of craniometric characters impossible, but it does permit of easily establishing which the characters are discriminant, and the analysis of the correlation relationships. The results obtained are thus useful as guides, since they form an pointer as to which characters should primarily be considered in continued research on similar populations.

All the characters we examined exhibited, in both males and females, significant age variation. The most distinctive were as follows: in males - maximum length of skull and postorbital breadth, in females - nasal breadth. Postorbital breadth is greater in young than in adult sousliks in both sexes. This interesting fact is yet another indicator that this character is different from others (see section V.1.).

The occurrence as the most distinctive of different characters in males than in females points to the differences between the sexes as regards the development processes of the skull. In males the skull primarily lengthens with age, and the breadth of the frontal part decreases (the front narrows). In females it is chiefly the rostrum which broadens.

In both sexes the closest correlation connection $(r>0.5)$ is exhibited by the following characters: maximum length of skull with length of mandible; maximum length of skull with nasal breadth; maximum length of skull with height, of brain case; nasal breadth with mandibular length.

The first correlation is, as can be seen from the analyses made so far, both very common and constant. It forms evidence of the even development of the skull in the sagittal plane, the mandible skeeping up " in growth with the upper parts of the skull. The second and fourth correlations became evident when considering sex dimorphism in the group of young sousliks.

The correlation between maximum length of skull with height of brain case appeared here as a new one. Its existence demonstrates the 
even development of the souslik's skull in length and height. Grulich (1960) reaches slightly different conclusions in his study on $\mathrm{C} i$ tellus citellus, but this description is not statistically documented.

Among the correlation connections revealed in the above analyses it is possible to distinguish several types of connection:

a) Correlations between two measurements due to the fact of topographical proximity of measuring points $-e . g$. Cb length and maximum length of skull.

b) Correlations between two measurements embracing one craniological whole in two planes - e. g. maximum length of skull and height of brain case: mandible length and height. Such correlations are evidence of the even development of the given whole part in both these planes.

c) Correlations between two measurements made in the same plane - e. g. maximum length of skull and mandibular length. Such correlations are evidence of the even growth of different parts of the skull in the given plane.

d) Correlations between two characters referring to regions of the skull physiologically connected with each other, e. $g$. by the action of the same muscles. An example of such correlation is formed by the connection between posterior zygomatic breadth and mandibular length.

e) Correlations between two characters forming the result of correlating these two characters with a third character - correlation between $\mathrm{Cb}$ length and mandibular height can be explained by the connection of these characters with mandibular length.

f) Correlations which cannot be directly allocated to any of the preceding groups $-e . g$. nasal breadth and mandibular length.

\section{REFERENCES}

1. Bond Ch. F., 1956: Correlations between reproductive condition and skull characteristic of beaver (Castor canadensis). J. Mamm., 37, 4: 506-512.

2. Caboh-Raczyńska K., 1964 a: Correlations of skull measurements of Lepus europaeus Pallas, 1778. Acta theriol., 8, 13: 207-216.

3. Caboń-Raczyńska K., 1964 b: Studies on the European hare. III. Morphological variability of the skull. Acta theriol., 9, 17: 249-285.

4. Cockrum E. L, 1954: Nongeographic variation in cranial measurements of wild-taken Peromyscus leucopus noveboracensis. J. Mamm., 35, 3: 367376.

5. Dehnel A., 1949: Badania nad rodzajem Sorex L., Annls Univ. M. CurieSkłodowska, C 4, 2: 17-102. Lublin.

6. Dubois G., 1927: Notes craniologiques sur quelques especes de Citellus eurasiatiques. Ann. Soc. Royals Zool. de Belgique, 58: 13-70, Bruxelles.

7. Fisher R. A., 1936: The use of multiple measurements in taxonomic problems. Annals Eug., 7, 2; 179-188, 
8. Freedman L., 1963: A biometric study of Papio cynocephalus skulls from northern Rhodesia and Nyasaland. J. Mamm., 44, 1: 24-43.

9. Gentile J, 1952: A craniometric study of the Norway rat. J. Mamm., 33, 2: $190-197$.

10. Grulich I., 1960: Sysel obecny Citellus citellus L. v CSRS. Prace Brnenske zakladny Ceskoslovenske akademie ved, 32, 11: 473-561, Brno.

11. Migulin O. O., 1938: Zviri URSR. Materialy po faunie SSSR. Izd. Akad. Nauk. URSR, Kiev.

12. Obolenskij S., 1927: A preliminary reviev of the palearctic souslics Citellus and Spermophilopsis. Compt. rend. de l'Acad. des Scien. de l'URSS, 12.

13. Ognev S. T., 1937: Materialy po sistematikie palearktičeskih suslikov. Izd. Akad. Nauk SSSR, Moskva-Leningrad.

14. Ognev S. T., 1947: Zvieri SSSR i priležaščih stran. 5, Izd. Akad. Nauk. SSSR, Moskva-Leningrad.

15. Olekiewicz M., 1962: Klasyczna i sekwencyjna metoda dyskryminacji. Materialy i Prace Antropologiczne nr 61, Miscellanea, 6: Wrocław.

16. Reichstein H., 1957: Schädelvariabilität europäischer Mauswiesel (Mustela nivalis L.) und Hermeline (Mustela erminea L.) in Beziehung zu Verbreitung und Geschlecht. Ztschr. Säugetierkde, 22, 3-4: 151-182. Hamburg.

17. R ešetnik E. G., 1946: O novyh podvidah krapčatogo suslika (Citellus suslica volhynensis subsp. nova i C. suslica ognevi subsp. nova). Bull. MOIP, otd. biol., 6: 25-28. Moskva.

18. Serebrennikov M. K., 1930: Vozrastnaja izmienčivost i process rosta čerepa u bielki (Sciurus vulgaris L.). Ežeg. zool. Muz. A. N., 31: 399-418. Leningrad.

19. Sidorowicz J., 1961: Craniometrical measurements of Scandinavian squirrels and their distribution. Acta theriol., 5, 17: 253-261.

20. Surdacki S., 1956: Susel perełkowany (Citellus suslica Gueld.) na Lubelszczyźnie. Annls Univ. M. Curie-Skłodowska, C 9, 7: 307-354. Lublin.

21. Surdacki $\mathrm{S}_{\text {, }}$ 1958: Untersuchungen auf zwei Populationen des Perlziesels (Citellus suslica Gueld.) in Lubliner Gebiet. Acta theriol., 2, 10: 203-234.

22. Surdacki S., 1963: Zmiany rozmieszczenia i liczebności Citellus suslica (G u el d.) na Lubelszczyźnie w okłresie 1954-1961. Ib., 7, 7: 79-90.

23. Surdacki S., 1963: Rozmieszczenie i zmienność susła moręgowanego, Citellus citellus (Linnaeus, 1766) w Polsce. Acta theriol., 10, 19: 273-288.

24. Wasilewski W., 1952: Badania nad morfologią Clethrionomys glareolus (S c hreb.). Annls Univ. M. Curie-Skłodowska, C 7, 3: 119-211. Lublin.

25. Vinogradov B. S. \& Gromov I. M., 1952: Gryzuny fauny SSSR. Opredielitiel po faunie SSSR. Izd. Akad. Nauk SSSR. Moskva-Leningrad.

Received, October 19, 1967.

Department of Zoology

\& Department of Mathematical Statistics,

Warsaw Agricultural University,

Warszawa, Rakowiecka 8. 
Acknowledgements: Mammals Research Institute of the Polish Academy of Sciences at Białowieża subsidised capturing animals and preparation of skulls for this study, and is the owner of whole material used. The authors are very grateful to Professors A. D ehnel (Białowieża), Z. R a a be (Warsaw) and Z. K a w e cki (Warsaw) for their valuable remarks and discussions on biological part of this study and Professors Z. Nawrocki and J. Oderfeld (both Warsaw) on statistical part.

\section{Barbara CIESIELSKA \& Witold KUPSC}

\section{KRANIOMETRYCZNA ZMIENNOSĆ POPULACJI SUSEA PEREEKOWANEGO}

\section{Streszczenie}

Praca miala na celu zbadanie dymorfizmu płciowego i zmienności rozwojowej czaszki susła perełkowanego Citellus suslicus (G üldensta edt, 1770) w populacji ze Sławęcina pod Hrubieszowem. Materiał stanowiły 194 czaszki w tym 91 samców i 103 samic. Wprowadzono podzial na 2 grupy wiekowe: młode (niedojrzałe płciowo) - 134 osobniki, oraz dçrosłe - 60 osobników. Materiał został zebrany w okresie od 6 do 25 lipca $1955 \mathrm{r}$. W opracowaniu statystycznym posłużono się metodą analizy dyskryminacyjnej Fishera. Przebadano: (a) zróżnicowanie zbiorowości ze względu na zespół cech, (b) zróżnicowanie zbiorowości ze względu na każdą cechę niezależnie od zespołu, (c) wybiorczość poszczególnych cech w zespole, oraz (d) związki korelacyjne między cechami.

Dokonano 4-ch niezależnych porównań: 1) Porównanie dla płci w grupie wieku „dqrosłe" dla 13-tu cech. Wykazano istotne zróżnicowanie dymorficzne ze względu na zespół cech. Cechy rozpatrywane niezależnie również wykazały zróżnicowanie z wyjątkiem maksymalnej szerokości kości nosowych i szerokości postorbitalnej. Najsilniejszą wybiorczość wykazał zespół cech: maksymalna długość czaszki, maksymalna szerokość kości nosowych, szerokość postorbitalna, maksymalna wysokość puszki mózgowej oraz długość żuchwy. 2) Porównanie dla płci w grupie wieku „młode" dla 5-ciu cech. Wykazano zróżnicowanie dymorficzne ze względu na zespół cech, jak również ze względu na każdą cechę badaną niezależnie, Żadna $\mathrm{z}$ cech natomiast nie wykazuje wybiorczości w zespole. 3) Porównanie grup wiekowych wśród samców. Wykazano zróżnicowanie grup wiekowych dla zespołu 5-ciu cech i dla każdej cechy oddzielnie. Największą wybiorczość wykazują cechy: maksymalna długość czaszki i szerokość postorbitalna. 4) Porównanie grup wiekowych wśród samic dla 5-ciu cech. Wykazano istotność wyznaczonej funkcji dyskryminacyjnej oraz cech traktowanych niezależnie. Najsilniejszą wybiorczość wykazała maksymalna szerokość kości nosowych. 